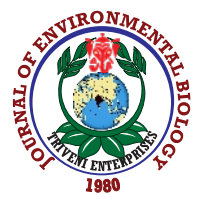

\title{
Potential of tasar silkworm (Antheraea mylitta) excreta as fertilizer on growth, yield and quality of rice
}

\author{
R.J. Mevada', D. Nayak ${ }^{2 *}$, D.P. Patel ${ }^{2}$ and M.B. Tandel ${ }^{1}$ \\ 'Department of Silviculture and Agroforestry, ASPEE College of Horticulture and Forestry, Navsari Agricultural University, Navsari - 396 450, India \\ ${ }^{2}$ Department of Natural Resource Management, ASPEE College of Horticulture and Forestry, Navsari Agricultural University, Navsari - 396 450, India \\ ${ }^{*}$ Corresponding Author Email : dileswarnayak@nau.in
}

\section{Abstract}

Aim: To investigate the integrated use of chemical fertilizer and potential tasar silkworm (Antheraea mylitta) excreta as fertilizer on the growth, yield and quality of rice.

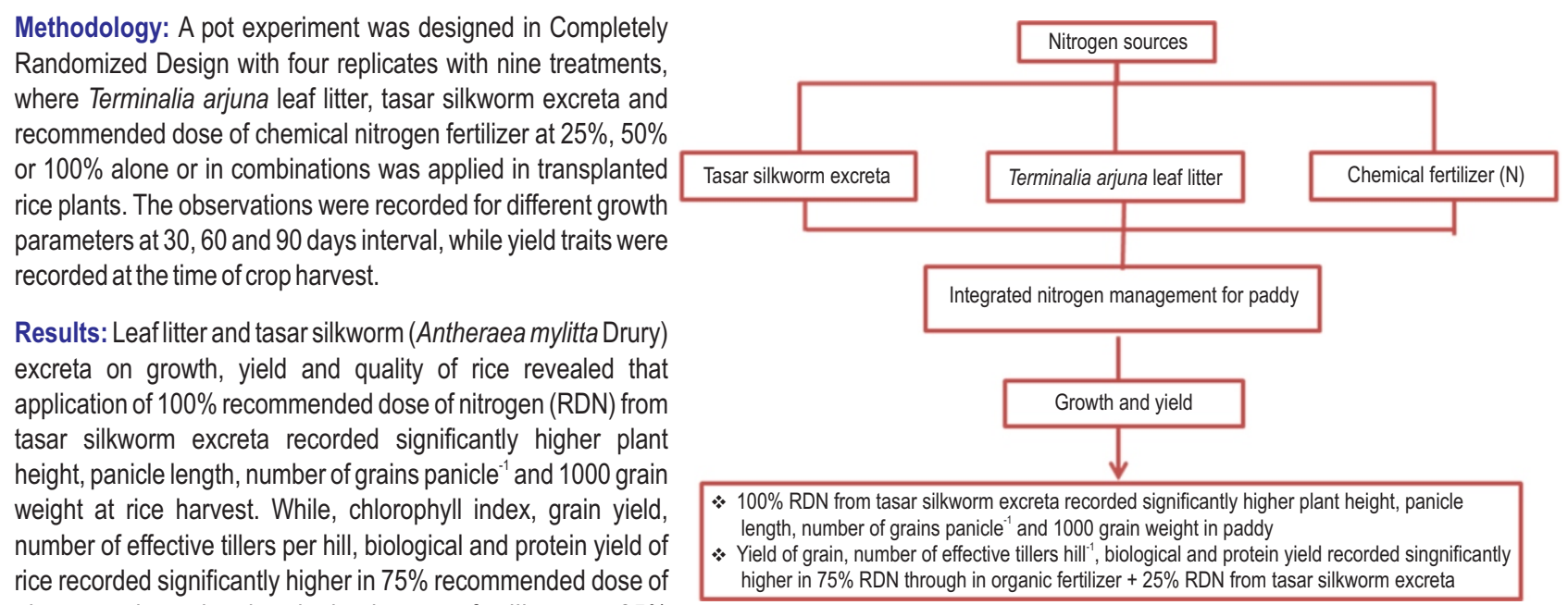
nitrogen through chemical nitrogen fertilizer $+25 \%$ recommended dose of nitrogen from tasar silkworm excreta. Nitrogen and protein content of grain recorded statistically higher in $50 \%$ recommended dose of nitrogen through inorganic fertilizer $+50 \%$ RDN from tasar silkworm excreta. Grain yield was significantly correlated with nitrogen uptake and protein yield, plant height, effective tillers per hill, 1000 grain weight, straw and biological yield.

Interpretation: Integrated use of $75 \%$ RDN through chemical nitrogen fertilizer with $25 \%$ RDN from tasar silkworm excreta is suitable for higher production that may reduce the external input of chemical nitrogen fertilizers and promote zero waste management.

Key words: Leaf litter, Nitrogen, Rice, Tasar silkworm excreta, Terminalia arjuna

How to cite : Mevada, R.J., D. Nayak, D.P. Patel and M.B. Tandel: Potential of tasar silkworm (Antheraea mylitta) excreta as fertilizer on growth, yield and quality of rice. J. Environ. Biol., 42, 1070-1077 (2021). 


\section{Introduction}

Sustainability of soil is utmost importance for ensuring global food security and nutrition. The vital challenge of soil is to maintain its fertility and other ecosystem services. Nitrogen is one of the major macro essential nutrients for crop production. The chemical nitorgen fertilisers are not environmental friendly and extensively used, will continue to grow to feed 9.7 billion people by 2050 . Further, animal protein and meat products are expected to increase from current demands by $75 \%$ in 2050 , insects may be an alternative option for conventional protein (Berggren et al., 2019). Traditionally many indigenous people still consume insect as food in South East Asian countries. Recently, commercial insect rearing for insect protein has been promoted and legally adopted in many European countries. Insect production also yields waste stream consisting of moulting skins (exuviae) and, more importantly, insect excreta (Dicke, 2018). In forests, frass deposition in soil has pronounced effect on soil fertility due to high nutrient content (Kagata and Ohgushi, 2012). Many organic sources like vermicompost, farmyard manure, oil cake, bone meal, human excretion have alternatively been used for nitrogen supply in agriculture.

Recently, excreta of bats, insects are also being tested as fertiliser in crop production. For example, black soldier fly frass for sugarcane (Pakpahan et al., 2020), mealworm frass used in barley (Houben et al., 2020), baby leaf lettuce, basil and tomato (Setti et al., 2019) as well as Nebrio molitor frass used in mung bean. Tasar silkworm Antheraea mylitta Drury (Lepidoptera: Saturniidae) is a herbivore economic insect, reared extensively on Terminalia arjuna (Roxb.) host for vanya silkworm, well distributed traditionally in farm bunds of tropical rice growing countries. Use of organic sources of nitrogen in modern days rice cultivation has resulted in low productivity and soil fertility. Moreover, soil fertility can be improved (Tiwari et al., 2002) by using combination of inorganic with organic manures. (Saikia et al., 2015). Even if rice is heavy nitrogen feeders, nitrogen use efficiency is very low usually ranges from 15 to $35 \%$ and rarely exceeds 50\% under tropical conditions (De Datta, 1986). Adequate use of nitrogen sources is very important, as it not only increases the yield but also reduce the cost of production and prevents environmental pollution (Fageria et al., 2011).

Therefore, new darification is needed to increase the yield of highly demanded most important cereal, rice supplying more than $16 \%$ global staple food. In such situation, on-farm integrated nitrogen nutrient management technology using agroforestry system seems to solve this issue, however freshly fallen leaf litter even though add organic nutrients takes long time to decompose and available. As rate of decomposition of leaf litter strongly depends on climatic variables (Bhalawe et al., 2013a), and also nitrogen release varied based on their relative elemental concentrations (Bhalawe et al., 2013b). Thus, nutrient availability momentum can be facilitated when tasar silkworm fed on green leaf for next step output as feces instead of leaf litter. The excreted litter added into the agro-ecosystems can availed quicker as compared to un-intervened nutrient cycling system. There is no such study yet been reported so far in tasar silkworm excreta as fertiliser, therefore this study was designed to assess the potential of tasar silkworm excreta on growth, yield and quality of rice.

\section{Materials and Methods}

Study area: A mesocomb experiment was conducted during kharif season 2016-17 in a polyhouse of ASPEE College of Horticulture and Forestry, Navsari Agricultural University, Navsari, India. The region experiences humid and warm monsoon with rainfall of about $1500 \mathrm{~mm}$, moderately cold winter, and fairly hot and humid summer. The average annual temperature is $27.1^{\circ} \mathrm{C}$.

Collection of soil media: To carry out mesocomb study, soil sample, leaf litter and tasar silkworm excreta were collected. Firstly, soil was collected at a depth of $0-15 \mathrm{~cm}$ randomly from previously cultivated rice field representing the whole area. The collected soil samples were mixed together to make a composite growing media for the mesocomb experiment. The physicochemical properties of soil were as follows. Electrical conductivity $0.36 \mathrm{dSm}^{-1}$, soil $\mathrm{pH} 7.91$, organic carbon $0.78 \%$, available $\mathrm{N} 117$ ppm; available $\mathrm{P}_{2} \mathrm{O}_{5} 38$ ppm and available $\mathrm{K}_{2} \mathrm{O} 210$ ppm in the growing media before treatments.

Collection of leaf litter and Tasar silkworm excreta: The leaf litters were collected from 15 year old $T$. arjuna raised in farm boundary. These freshly harvested leaf litters were dried and grinded to powdered form to prepare treatment combinations. Then tasar silkworm excreta sample was collected under controlled environmental condition. The fresh tasar silkworm excreta were collected by feeding $T$. arjuna tender leaves to $A$. mylitta insects during kharif season. The obtained tasar silkworm excreta was kept room temperature for drying and nitrogen content of tasar silkworm excreta (1.12\%) and leaf litter (0.504\%) was analysed using wet digestion method (Trivedi et al., 1999) before mesocomb experiment.

Treatment application: About $15 \mathrm{~kg}$ of soil media was filled in black colour mesocomb of $15 \mathrm{~mm}$ thickness. Nitrogen dose of each treatment for rice crop was quantified as per nitrogen content in tasar silkworm excreta and leaf litter. Correspondingly, rice seedlings (GNR-4) were raised in wet nursery before transplanting into the mesocomb. In this experiment, the recommended dose of NPK for rice was $100-30-00 \mathrm{~kg} \mathrm{ha}^{-1}$. The experimental treatments comprised of three sources of nitrogen, i.e., tasar silkworm excreta and leaf litter; chemical nitrogen fertiliser and various combinations. Chemical nitrogen fertiliser was applied in three split doses and of phosphorus dose was common to all treatments through basal application. The experiment was designed in a Completely Randomized Design in four replications with nine treatments. The following treatments were applied: $T_{1}$ : control treatment was without any external input 
of fertilizer; $T_{2}: 100 \%$ RDF (Recommended Dose of Fertilizer) through chemical fertilizers; $T_{3}: 75 \%$ RDN (Recommended Dose of Nitrogen) through chemical nitrogen fertilizer $+25 \%$ RDN from tasar silkworm excreta; $\mathrm{T}_{4}: 50 \%$ RDN through chemical nitrogen fertilizer + 50\% RDN from tasar silkworm excreta, $T_{5}: 75 \%$ RDN through chemical nitrogen fertilizer $+25 \% \mathrm{RDN}$ from leaf litter; $\mathrm{T}_{6}$ : $75 \%$ RDN through chemical nitrogen fertilizer $+25 \%$ RDN from leaf litter; $\mathrm{T}_{7}: 50 \% \mathrm{RDN}$ through chemical nitrogen fertilizer $+25 \%$ RDN from tasar silkworm excreta $+25 \%$ RDN from leaf litter; $T_{8}$ : $100 \%$ RDN from tasar silkworm excreta and $\mathrm{T}_{9}: 100 \%$ RDN from leaf litter only. Randomly five plants were selected in different five mesocombs for recording biometrical observations. Plant height and chlorophyll index was documented periodically at 30,60 , and 90 days after transplanting (DAT) and at harvest. The chlorophyll index was measured using SPAD 502 chlorophyll meter. The yield attributing traits like number of tillers per hill and effective tillers per hill, number of grains per panicle, 1000 grain weight, grain and straw yield was recorded at the time of harvest. Further quality of grain (protein content) was also analysed.

Statistical analyses: The recorded data were statistically analyzed and treatment means were compared by critical difference tests at 1 and $5 \%$ probability level and analysis of variance. Karl Pearson's correlation coefficient was calculated to determine the degree of association between crop yield and other traits.

\section{Results and Discussion}

The biometrical growth and yield of rice were affected significantly due to different organic and inorganic sources of nitrogen application. The contribution of nitrogen absorbed at different growth stages from different origins to total nitrogen varies with cultural practices (Wada et al., 1986). The type of $\mathrm{N}$ fertilizer affect growth, yield and grain quality in rice (Gately and Kelly, 1987) and periodical growth may also depend on the availability of nutrients. However, plant height is not an important yield attributing trait for grain crops, especially in rice; yet it influences the sources of nitrogen for plant metabolism. During early growth phase, the height was recorded significantly higher under the combined application of $75 \%$ chemical nitrogen along with $25 \%$ tasar silkworm excreta as shown in Fig. 1a. Nevertheless, later growth phase (90 DAT), i.e., the maximum plant height was recorded under $50 \%$ inorganic nitrogen along with $50 \%$ tasar silkworm excreta treatment.

On the other hand, the height of rice was significant, i.e., higher in $100 \%$ tasar silkworm excreta at the time of harvest. Lower height at early growth stage might have resulted in slow release of nutrients; supplied nutrients consistently over whole growing phase favored maximum height under 100\% tasar silkworm excreta. Similar report on cow dung vermicompost resulted in maximum plant height in soyabean (Mariammal et al., 2012) whereas $100 \%$ organic nitrogen sources from leaf litter produced the lowest plant height as compared to control; as leaf litter might release allelochemicals during decomposition process which inhibits the growth of rice (Kuiters, 1990). Tillering is an important vegetative trait for rice yield and grain production. Therefore, appropriate nutrient management approach can not only increase the number of tiller but also improve the grain (Fig. 1b). The number of tillers per hill at 60,90 DAT and number of effective tillers per hill during harvest were influenced significantly due to their individual effect of organic sources.

Among the treatments, $75 \%$ RDN through chemical fertilizer $+25 \%$ RDN from tasar silkworm excreta recorded significantly higher number of tillers per hill in all stages. This may be due to the interactive effect of silkworm excreta with chemical fertilizers which increased the nutrient availability and rice uptake. (Satyanarayana et al., 2002). According to Bhuiya and Akhand, (1982). The number of tillers increased due to combined application of mustard oil cake/cow dung and chemical fertilizers. In fact, rice is productivity influenced by the number of productive tiller rather than total number of tillers. Hence, single or combined use of organic and inorganic nutrients has significant effect on the number of productive tillers as compared to control. Therefore, the maximum number of effective tillers per hill were observed in $75 \%$ RDN through chemical fertilizer + $25 \%$ RDN from tasar silkworm excreta and it was at par with 100\% RDF through chemical fertilizers as well as $75 \%$ RDN through chemical fertilizer $+25 \%$ RDN from tasar silkworm excreta. It also is presumed that split application of chemical nitrogen fertilizer alone as well as combined with tasar silkworm excreta favors to increase the number of effective tillers. As combined applications of organic and inorganic nutrient significantly promote increase in total nitrogen content and soil organic carbon (Mevada et al., 2018) and improve available essential micro nutrients (Satyanarayana et al., 2002; Rakshit etal., 2008).

Panicle length is another important trait in rice panicle architecture for yield (Liu et al., 2016) and influences the grain number, grain density and rice quality (Wang et al., 2019). Here, the maximum panicle length was recorded with $100 \%$ RDN from tasar silkworm excreta as compared to other treatments (Table 1). Significant response may be due to optimised nitrogen application (Zhou et al., 2017). Interestingly, application of 100\% tasar silkworm excreta may positively influence for higher available soil phosphorus and potash content (Mevada et al., 2018). Increase in available phosphorus in soil suggests phosphorus uptake from soil during grain filling is a critical contributor to grains in rice, but phosphorus potentially remobilized (20\%) in panicle from total phosphorus accumulated in aerial vegetative parts (Julia et al., 2016). Therefore, higher panicle length was recorded under $100 \%$ tasar silkworm excreta as compared to other organic sources. The increase in panicle length, number of grains per panicle in 100\% RDN of tasar silkworm excreta recorded significantly higher which was at par with other treatments $\left(T_{1}, T_{2}, T_{3}, T_{4}\right.$ and $\left.T_{7}\right)$. The effect of organic sources of nitrogen increased the number of grains per panicle was pronounced as compared to chemical fertilizers. Similarly, 1000 grain weight was significantly affected by different treatments. It was estimated that significantly higher test weight 

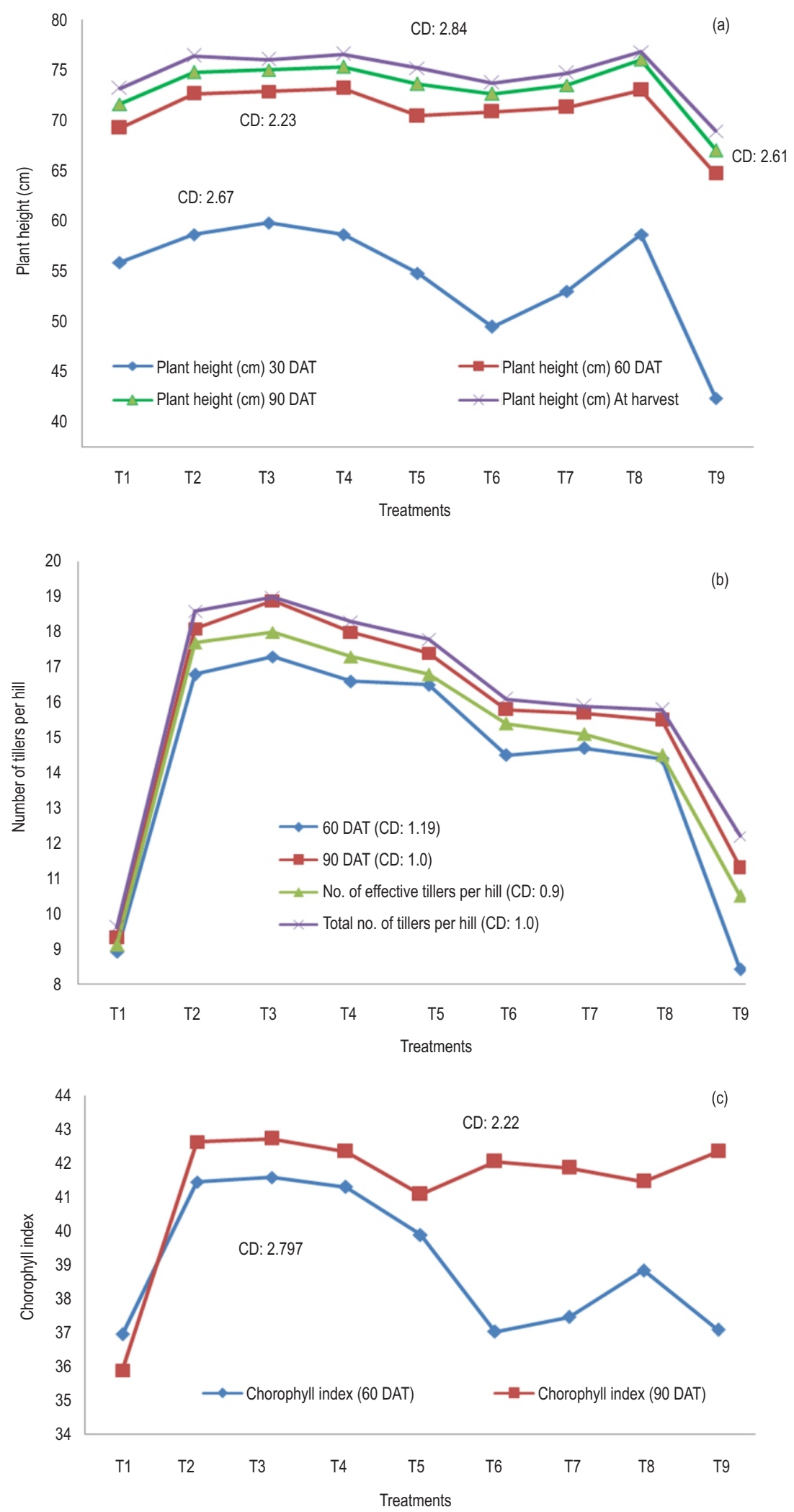

Fig. 1: Effect of T. arjuna leaf litter and tasar silkworm excreta on (a) plant height (cm) during various growth stages; (b) total number of tillers and effective tillers hill ${ }^{-1}$ and (c) chlorophyll index in rice. 
Table 1: Effect of T. arjuna leaf litter and tasar silkworm excreta on panicle length, number of grains, 1000 seed weight, grain, straw and biological yield in rice

\begin{tabular}{lllllll}
\hline Treatments & $\begin{array}{l}\text { Panicle length } \\
\text { (cm) }\end{array}$ & $\begin{array}{l}\text { Number of grains } \\
\text { per panicle }\end{array}$ & $\begin{array}{l}1000 \text { grain } \\
\text { weight } \mathbf{( g )}\end{array}$ & $\begin{array}{l}\text { Grain yield } \\
\text { (g per pot) }\end{array}$ & $\begin{array}{l}\text { Straw yield } \\
\text { (g per pot) }\end{array}$ & $\begin{array}{l}\text { Biological yield } \\
\text { (g per pot) }\end{array}$ \\
\hline $\mathrm{T}_{1}$ & 18.0 & 216.8 & 15.88 & 35.6 & 47.4 & 83.0 \\
$\mathrm{~T}_{2}$ & 17.8 & 216.8 & 16.20 & 64.8 & 81.8 & $14 \mathrm{~s} 6.5$ \\
$\mathrm{~T}_{3}$ & 18.0 & 223.8 & 16.26 & 66.9 & 81.4 & 148.2 \\
$\mathrm{~T}_{4}$ & 17.1 & 217.8 & 16.25 & 66.1 & 76.3 & 142.4 \\
$\mathrm{~T}_{5}$ & 17.1 & 193.8 & 16.11 & 57.7 & 68.4 & 126.1 \\
$\mathrm{~T}_{6}$ & 16.9 & 188.0 & 15.76 & 56.1 & 58.2 & 114.3 \\
$\mathrm{~T}_{7}$ & 17.8 & 223.0 & 16.01 & 48.7 & 56.3 & 105.0 \\
$\mathrm{~T}_{8}$ & 18.1 & 228.0 & 16.36 & 50.5 & 63.4 & 113.9 \\
$\mathrm{~T}_{9}$ & 16.1 & 185.0 & 14.79 & 33.2 & 33.4 & 66.6 \\
S.Em.t. & 0.51 & 4.93 & 0.13 & 1.28 & 1.49 & 2.16 \\
C.D.@5\% & NS & 14.31 & 0.39 & 3.70 & 4.31 & 6.27 \\
C.V(\%) & 5.83 & 4.69 & 1.66 & 4.79 & 4.72 & 3.72 \\
\hline
\end{tabular}

Table 2: Effect of T. arjuna leaf litter and tasar silkworm excreta on nitrogen content, protein content, uptake of nitrogen and protein yield in rice grain

\begin{tabular}{lllll}
\hline Treatments & $\begin{array}{l}\text { Nitrogen } \\
\text { content (\%) }\end{array}$ & $\begin{array}{l}\text { Nitrogen uptake } \\
\text { (g per pot) }\end{array}$ & $\begin{array}{l}\text { Protein } \\
\text { content (\%) }\end{array}$ & $\begin{array}{l}\text { Protein yield } \\
\text { (g per pot) }\end{array}$ \\
\hline $\mathrm{T}_{1}$ & 1.43 & 0.51 & 8.96 & 3.20 \\
$\mathrm{~T}_{2}$ & 1.68 & 1.09 & 10.51 & 6.81 \\
$\mathrm{~T}_{3}$ & 1.76 & 1.18 & 11.00 & 7.35 \\
$\mathrm{~T}_{4}$ & 1.78 & 1.18 & 11.12 & 7.35 \\
$\mathrm{~T}_{5}$ & 1.76 & 1.02 & 11.03 & 6.37 \\
$\mathrm{~T}_{6}$ & 1.80 & 1.01 & 11.23 & 6.29 \\
$\mathrm{~T}_{7}$ & 1.74 & 0.84 & 10.85 & 5.27 \\
$\mathrm{~T}_{8}$ & 1.72 & 0.87 & 10.73 & 5.42 \\
$\mathrm{~T}_{9}$ & 1.76 & 0.58 & 11.01 & 3.65 \\
S.Em. & 0.03 & 0.03 & 0.20 & 0.16 \\
C.D.@5\% & 0.09 & 0.08 & 0.57 & 0.46 \\
C.V(\%) & 3.68 & 5.66 & 3.68 & 5.50 \\
\hline
\end{tabular}

was recorded with $100 \%$ RDN from tasar silkworm excreta which was at par with $T_{2}, T_{3}, T_{4}, T_{5}$ and $T_{7}$ treatments. Increase in grain yield may be due to balanced nutrient availability, improved nitrogen as well as other macro and micro elements absorbed, resulted in enhance production and translocation of dry matter content from source to sink in rice (Morteza et al., 2010). The grain and straw yield of rice was significantly affected by different nitrogen sources. It is evident that grain yield was determined by combined action of different yield contributing factors like number of effective tillers, panicle length, filled grain, and 1000 grain weight (Saha et al., 2012).

Among the treatments, $75 \%$ chemical nitrogen with $25 \%$ tasar silkworm excreta produced significantly higher grain yield, but straw yield was significantly higher in 100\% chemical nitrogen. Integrated application of 50\% RDF of NPK through chemical fertilizers and $50 \%$ through sheep manure produced significant improvement in growth and yield attributes of grasses
(Meena et al., 2017). Conversely, straw yield was highest in 100\% chemical nitrogen, followed by $75 \%$ chemical nitrogen along with $25 \%$ tasar silkworm excreta. However, higher biological yields obtained from $75 \%$ chemical nitrogen $+25 \%$ tasar silkworm excreta treatment may be due to higher yield attributes in rice (plant height, number of effective tillers per hill, grain, straw). Further, $100 \%$ RDF $+75 \%$ organic manure increases the growth and yield attribute, which was followed by $50 \%$ RDF $+50 \%$ organic manure for maize crop (Shanmugam and Ramamoorthy, 2014). Chlorophyll index is one of the most important physiological parameters. In this study, significantly higher chlorophyll index was observed in rice with $75 \%$ RDN through chemical fertilizer combined with $25 \%$ RDN (Fig. 1c).

Exceptionally rice chlorophyll index increased in all treatments, except control. Therefore, the current findings are in line with Amujoyegbe et al. (2007) who demonstrated the influence of inorganic fertilizers, poultry manure alone, and or in combination on chlorophyll component. That combined treatment 


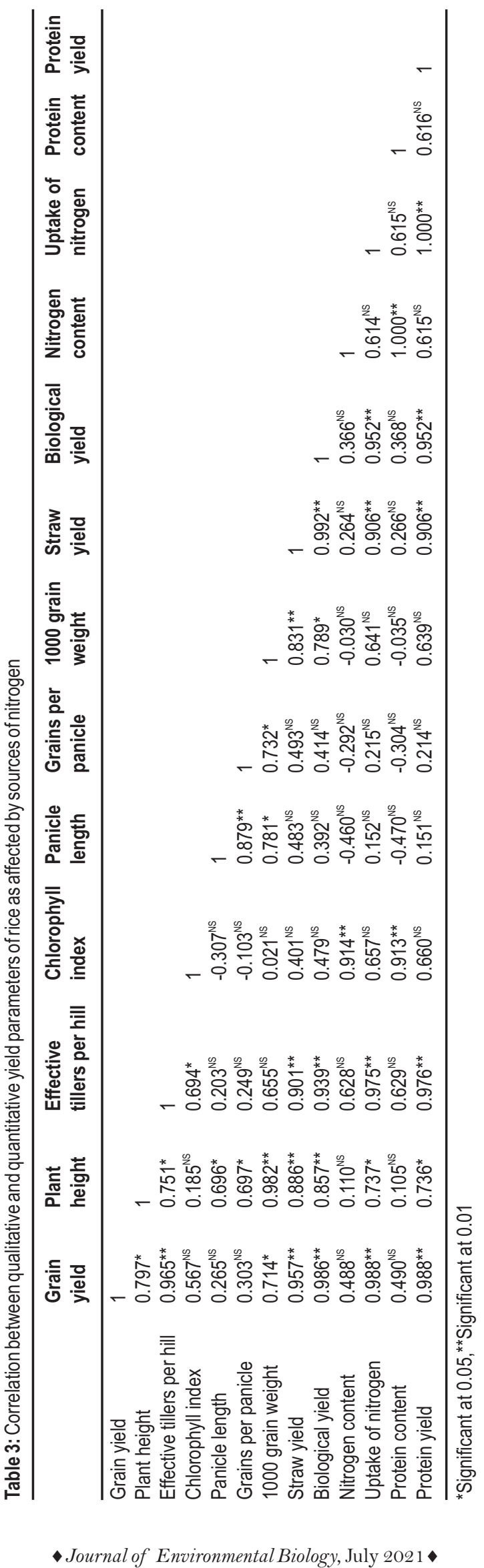


exhibited higher chlorophyll $a$ and $b$ in sorghum and maize. Integrated management of nutrients influences significantly on nitrogen and protein content in rice grain is presented in Table 1. Nitrogen and protein content was recorded significantly higher with $50 \%$ RDN through chemical fertilizer $+50 \%$ RDN from tasar silkworm excreta. Improve in grain quality owing to its integrated use of organic and chemical fertilizers attributed to its involvement in nitrogen metabolism and combined use of chemical fertilizer and municipal waste compost increased the nitrogen content in rice as compared to application of chemical fertilizers alone (Heenkende and Parama, 2010). Increased nitrogen application can increase protein content in wheat grain significantly (Zhang etal., 2017).

Significantly higher nitrogen uptake and protein yield were recorded with both $75 \%$ RDN through chemical fertilizer + $25 \%$ RDN from tasar silkworm excreta and 50\% RDN through chemical fertilizer $+50 \%$ RDN from tasar silkworm excreta, because higher grain yield and protein content in these treatments also increased the protein content. Patil et al. (2000) recommend that increase in fish manure level also increase the protein content in rice grain. The quality of rice grain with respect to protein content significantly improved with the integrated use of organic fertilizer with nitrogen as a chemical fertilizer (Ram et al., 2000). The source of nitrogen fertilizer application is strongly related to crop yield. The relationship of yield and quality in rice varied with all studied characters (Table 3). Grain yield was found to be significantly correlated with each other for quality parameters like nitrogen uptake and protein yield, plant height, effective tillers per hill, 1000 grain weight, straw and biological yield at 1 and $5 \%$ probability. The grain yield was significantly correlated due to positive relationship of plant height with number of effective tillers per hill, 1000 grain weight, straw and biological yield and also with grain quality parameters viz. nitrogen uptake and protein yield, because yield is closely related to plant height and better height may improve rice yield (Li et al., 2019).

This is true, if plant height is an undesirable trait for lodging resistant varieties in rice, in such situation yield can be improved with higher plant height (Zhang et al., 2017). Also, the number of effective tillers per hill is a direct yield attributing character is significantly correlated to quality parameters like chlorophyll index, nitrogen uptake and protein yield including grain yield, plant height, straw and biological yield. However, panicle length, number of grains per panicle, 1000 grain weight as well as nitrogen and protein content in grain might not have contributed significantly to number of tillers per hill. The combined application of $75 \%$ RDN through chemical fertilizer $+25 \%$ RDN from tasar silkworm excreta improves the quantity and quality of rice yield. Thus, tasar silkworm excreta considerably reduced the amount of inorganic fertilizer input without compromising potential yield.

\section{Acknowledgment}

We extend our thanks to the Principal and Dean, ASPEE College of Horticulture and Forestry, Navsari Agricultural
University, Navsari, Gujarat, India for suggestions and providing all necessary facilities to carry out this research is highly acknowledged.

\section{Add-on Information}

Authors' contribution: R.J. Mevada: Experimentation, manuscript preparation, result analysis \& first draft manuscript preparation, D. Nayak: Conception, design of experiment, results and discussion and manuscript review, D.P. Patel: Result analysis and discussion, M.B. Tandel: Result analysis and discussion, review.

Research content: The research content is original and has not been published elsewhere.

\section{Ethical approval: Not applicable}

Conflict of interest: The authors declare that there is no conflict of interests.

\section{Data from other sources: Not applicable}

Consent to publish: All authors agree to publish the paper in Journal of Environmental Biology.

\section{References}

Amujoyegbe, B.Y., J.T. Opbode and A. Olayinka: Effect of organic and inorganic fertilizer on yield and chlorophyll content of maize (Zea mays L.) and sorghum Sorghum bicolor (L.) Moench). African J. Biotechnol., 46, 186-174 (2007).

Berggren, Å., A. Jansson and M. Low: Approaching ecological sustainability in the emerging insects as food industry. Trends Ecol. Evol., 34, 132-138 (2019).

Bhalawe, S., D. Nayak, M.U. Kukadia and P. Gayakvad: Leaf litter decomposition pattern of trees. Bioscan, 8, 1135-140 (2013a).

Bhalawe, S., M.U. Kukadia and D. Nayak: Nutrient release pattern of decomposited leaf litter in different multipurpose trees. Indian For., 139, 212-217 (2013b).

Bhuiya, M.R. ans M.S. Akhand: Effect of different source of organic material alone and in combination with two fertilizer level on growth parameters and composition of rice. Bangladesh J. Agr. Res., 7, 32-39 (1982).

De Datta, S.K.: Improving nitrogen fertilizer efficiency in low land rice in tropical Asia. Fertiliser Res., 9, 171-186 (1986).

Dicke, M.: Insects as feed and the sustainable development goals. J. Insects Food Feed, 4, 147-156 (2018).

Fageria, N.K., A.B. Dos Santos and T. Cobucci: Zinc nutrition of lowland rice. Comm. Soil Sci. PlantAnal., 42, 1719-1727 (2011).

Gately, T.F. and D. Kelly: Sources of nitrogen for spring barley. Soils and Grassland Production Research Report A Foras Taluntais, Dublin, pp. 27-28 (1987)

Heenkende, A.P. and V.R.R. Parama: Effect of silkworm pupae compost on soil $\mathrm{N}$ mineralization, nutrient uptake, crop yield and plant nutrient contents of French Bean (Phaseolus vulgaris L.). J. Sustain. Trop. Agric. Res., 21, 391-397 (2010).

Houben, D., G. Daoulas, M.P. Faucon and A.M. Dulaurent: Potential use of mealworm frass as a fertilizer: Impact on crop growth and soil 
properties. Sci. Rep., 10, 4659 (2020).

Julia, C., M. Wissuwa, T. Kretzschmar, K. Kwanho and T. Rose: Phosphorus uptake, partitioning and redistribution during grain filling in rice. Ann. Bot., 118, 1151-1162 (2016).

Kagata, H. and T. Ohgushi: Positive and negative impacts of insect frass quality on soil nitrogen availability and plant growth. Popul. Ecol., $54,75-82(2012)$.

Kuiters, A.T.: Role of phenolic substances from decomposing forest litter in plant-soil interactions. Acta Bot. Neerl., 39, 329-348 (1990).

Li, R., M. Li, U. Ashraf, S. Liu and J. Zhang: Exploring the relationships between yield and yield-related traits for rice varieties released in China from 1978 to 2017. Front. Plant Sci., 10, 543 (2019).

Liu, E., Y. Liu, G. Wu, S. Zeng, T.G. Tran Thi, L. Liang, Y. Liang, Z. Dong, D. She, H. Wang, I.U. Zaid and D. Hong: Identification of a candidate gene for panicle length in rice (Oryza sativa L.) via association and linkage analysis. Fron. Plant Sci., 7, 596 (2016).

Mariammal, D., K.M. Maruthi and M. Narayanan: Effect of silkworm litter mixed with spent mushroom agro wastes vermicompost on growth and yield of soybean (Glycine max. (L.) Merrill). Int. J. Adv. Lif. Sci., 5, 119-125. (2012).

Meena, L.R., R.S. Yadav and S. Kumar: Enhancing productivity, profitability and soil health through integrated nutrient management in ber-based hortipasture system in Rajasthan. Range Manag. Agrofor., 38, 100-107 (2017).

Mevada, R.J., D. Nayak and D.P. Patel: Impact of Terminalia arjuna (Roxb.) leaf litter and hosted tasar silkworm excreta on quality of paddy and soil properties. Int. J. Curr. Microbiol. Appl. Sci., 7, 3781-3789 (2018).

Morteza, S., A. Nasiri and S.L. Laware: Effects of organic fertilizers on growth and yield components in rice (Oryza sativa L.). J. Agric. Sci., 3, 217-224 (2010).

Pakpahan, A., Widowati R. and A. Suryadinata: Black soldier fly liquid biofertilizer in Bunga Mayang sugarcane plantation: From experiment to policy implications, MOJ Eco. Environ. Sci., 5, 89-98 (2020).

Patil, S.H., S.C. Talashilkar and V. Mehta: Integrated nutrient management using fish meal and fertilizer for rice (Oryza sativa). Indian J. Agric. Sci., 70, 31-33 (2000).

Rakshit, A., N.C. Sarkar and G.C. Jhan: Influence of organic manures on productivity of two varieties of rice. J. Cent. Eur. Agric., 9, 629-634 (2008).
Ram, R.P.S., B.B. Chauhan and A.L. Singhet: Integrated use of organic and fertilizer nitrogen in rice (Oryza sativa). Indian J. Agric. Sci., 70, 114-116 (2000).

Saha, P.K., S.M.M. Islam, M. Akter and S.K. Zaman: Nitrogen response behaviour of developed promising lines of T. Aman rice. Bangladesh J. Agric. Res., 37, 207-213 (2012).

Saikia, R., Das, T. and D.N. Das: Physico-chemical qualities of water in high altitude rice farming system of Ziro valley, Arunachal Pradesh, India. J. Env. Biol., 36, 1153-1159 (2015).

Satyanarayana, V., P.V.V. Prasad, V.R.K. Murthy and K.J. Boote: Influence of integrated use of farmyard manure and inorganic fertilizers on yield and yield components of integrated lowland rice. J. Plant Nutri., 25, 2081-2090 (2002).

Setti, L., E. Francia, A. Pulvirenti, S. Gigliano, M. Zaccardelli, C. Pane, F. Caradonia, S. Bortolini, L. Maistrello and D. Ronga: Use of black soldier fly (Hermetia illucens (L.), Diptera: Stratiomyidae) larvae processing residue in peat-based growing media Leonardo, Waste Manage., 95, 278-288 (2019).

Shanmugam, R. and K. Ramamoorthy: Effect of recycling of serivermicompost on growth, yield and nutrients of maize (Zea mays). J.Agric. Sci., 84, 982-986 (2014).

Tiwari, A., A.K. Dwivedi and P.R. Dikshit: Long term influence of organic and inorganic fertilization on soil fertility and productivity of soybean-wheat system in a Vertisol. J. Indian Soc. Soil Sci., 50, 472-475 (2002).

Trivedi, B.S., G.G. Patel, R.M. Desai and G.M. Padhiyar: Comparison of Kjeldahl's and chromic acid method of nitrogen determination. GujaratAgric. Uni. Res. J., 25, 9-14 (1999).

Wada, G., S. Shoji and T. Mae: Relationship between nitrogen absorption and growth and yield of rice plants. JapanAgr. Res. Q., 20,137-145(1986).

Wang, X., Liu Guifu, Z. Wang, S. Chen, Y. Xiao and Y. Chuanyuan: Identification and application of major quantitative trait loci for panicle length in rice (Oryza sativa) through single segment substitution lines. Plant Breed., 138, 299-308 (2019).

Zhang, P., G. Ma, C. Wang, H. Lu, S. Li, Y. Xie, D. Ma, Y. Zhu and T. Guo: Effect of irrigation and nitrogen application on grain amino acid composition and protein quality in winter wheat. PLOS ONE, 12, 115 (2017).

Zhou, W., T. Lv, Z. Yang, T. Wang, Y. Fu, Y. Chen, B. Hu and W. Ren: Morpho-physiological mechanism of rice yield increase in response to optimized nitrogen management. Sci. Rep., 7, 17226 (2017). 